\title{
Role of Media in Promoting Accountability and Transparency in Kakamega County Government - Kenya.
}

\author{
Mr. Wafula Nyongesa* \\ Masinde Muliro University of Science and Technology MMUST Kakamega, Kenya
}

*Corresponding Author: Mr. Wafula Nyongesa, Masinde Muliro University of Science and Technology MMUST Kakamega, Kenya

\begin{abstract}
An objective, free and skilled media is an essential component of any devolved unit. On the one hand, it provides the information which the polity require to make responsible, informed decisions. On the other, it performs a "checking function" ensuring that elected officials uphold their oaths of office and campaign promises and that they carry out the wishes of the electorate. Despite the mass media's propensity for sleaze, sensationalism and superficiality, the notion of the media as, watchdog, as guardian of the public interest, and as a conduit between governors and the governed remains deeply ingrained. African countries have increasingly adopted devolution as a strategy to improve governance and remedy institutional deficiencies that highly centralized governments have engendered. These include bureaucratic inefficiencies, poor accountability and transparency, unequal distribution of resources and low levels of community participation in development.
\end{abstract}

Keywords: Media, Devolution, Accountability, Transparency, Development Communication.

\section{INTRODUCTION}

The promulgation of the Constitution of Kenya 2010 marked a major milestone in the way the country is governed. It stipulated the dispersal of political power and economic resources from the centre to the grassroots in a process known as devolution. As a result, 47 county governments and the Senate were established following

The primary objective of decentralization is to devolve power, resources and representation down to the local level. Specifically, the objects of devolution of government in Kenya were to promote democratic and accountable exercise of power; foster national unity by recognizing diversity; give powers of self-governance to the people and enhance the participation of the people in the exercise of the powers of the State and in making decisions affecting them; and recognize the right of communities to manage their own affairs and further their development.

Democracy requires the active participation of citizens. Ideally, the media should keep citizens engaged in the business of governance by informing, educating and mobilizing the public. In Kakamega county, radio has become the medium of choice, as it is less expensive and more accessible. FM and community radio have been effective instruments for promoting grassroots democracy and enhancing transparency and accountability by airing local issues and providing an alternative source of information to official channels. The stations produce 'local content' in the 'local language', thus giving people a chance to contribute their views on the programmes relevant to their needs. These include programmes on farming, health, environment, and business.

Numerous studies document mass media impacts on public opinion and the agenda of policymakers (Dearing \& Rogers, 1996; McCombs \& Reynolds, 2002). People depend on the media for vital information that will help them understand what Is going on around them and to make informed decisions about their lives. This is especially true when they feel that a situation is ambiguous or there is a crisis of some sort (Ball-Rokeach, 1985).

\subsection{Structure of the County Government of Kakamega}

Kakamega County is a product of the 2010 Constitution of Kenya. The new Constitution spells out the Units of the devolved Government. The powers are provided for in Articles 191 and 192 and in the Fourth Schedule of the Constitution of Kenya and the County Governments Act of 2012. 
Role of Media in Promoting Accountability and Transparency in Kakamega County Government Kenya.

Kakamega, therefore, is one of the 47 Counties of Kenya. Following the re-organization of Kenya's national administration, Counties were integrated into new national administration with an elective Governor as the Chief Executive. The National Government, however, post County Commissioners to represent it at the Counties.

Figure1. Kakamega County Administrative and Political units.

\begin{tabular}{|c|c|c|c|c|c|}
\hline Constituencies & Sub-counties & $\begin{array}{l}\text { Area } \\
\text { Km2 }\end{array}$ & No. of divisions & $\begin{array}{l}\text { No. of } \\
\text { Locations }\end{array}$ & $\begin{array}{l}\text { No. of Sub } \\
\text { locations }\end{array}$ \\
\hline BUTERE & Butere & 210.5 & 3 & 8 & 25 \\
\hline KHWISERO & Khwisero & 145.6 & 2 & 7 & 20 \\
\hline LURAMBI & Kakamega Central & 244.5 & 2 & 6 & 12 \\
\hline NAVAKHOLO & Navakholo & 175.1 & 1 & 3 & 10 \\
\hline SHINYALU & Kakamega East & 445.5 & 2 & 6 & 23 \\
\hline \multirow{2}{*}{$\begin{array}{l}\text { KAKAMEGA } \\
\text { NORTH }\end{array}$} & Kakamega North & 427.4 & 5 & 14 & 52 \\
\hline & Matete & 100.2 & 1 & 2 & 7 \\
\hline IKOLOMANI & Kakamega South & 143.6 & 2 & 6 & 22 \\
\hline LIKUYANI & Likuyani & 301.8 & 1 & 4 & 8 \\
\hline LUGARI & Lugari & 265.8 & 1 & 4 & 8 \\
\hline MATUNGU & Matungu & 275.8 & 1 & 2 & 13 \\
\hline MUMIAS WEST & \multirow[b]{2}{*}{ Mumias } & \multirow{2}{*}{\multicolumn{2}{|c|}{314.5}} & \multirow{2}{*}{\multicolumn{2}{|c|}{30}} \\
\hline MUMIAS EAST & & & & & \\
\hline TOTAL & 12 & 3050.4 & 24 & 72 & 233 \\
\hline
\end{tabular}

\section{REVIEW OF RELATED LITERATURE}

Development Communication has evolved in parallel to the main development approaches over time. It's 'modification' can be traced to the general development thinking from a top-down, linear paradigm to a more participative, bottom-up thinking. While the concept of Communication for Development had already appeared in the 1960s, the prevailing modernization theory served as the dominant paradigm, also for Development Communication (Waisbord 2001). In those years its theorists saw nothing more in a communication process than a message going from sender to receiver (Lasswell 1946). The schools of thought were dominated by behaviour change models, holding the view that problems of development are rooted in lack of knowledge and that providing people with information will be the solution to foster development (Servaes 1996).

This thinking was led by 'diffusion' studies (Daniel Lerner 1958, Wilbur Schramm 1964). Daniel Lerner and Wilbur Schramm have been the main theorists of this phase, promoting development strategies with a strong "pro- media, pro-innovation, and pro-persuasion focus." Emphasis was placed on media technology as channels and indicators of modernization and development in the current time definition (Waisbord 2001). Even more influential became the "diffusion of innovations" theory inserted by Everett Rogers (Rogers 1962/1983). He stated that innovations diffuse over time according to people's stages, distinguishing between early adopters of innovations and those who are slower in adoption, which he assured to be the majority of development countries populations. According to this view of a transmission bias he can be traced in one line with Lerner and Schramm (Waisbord 2001).

While the concept of Participation in Development emerged on the development agenda in the 1970s, there were different meanings of participation within the development community. The currently prevailing belief, adopted by UNICEF in 1990 and broadly accepted in recent development circles is that participation only succeeds by actively involving people in the processes and over the decisions influencing their lives. This crucial aspect criticized that people will only consider changes as relevant if they can make their voices heard and be able to directly participate. Otherwise, it has been argued that people will feel less ownership over the process and will be less ambitioned to invest and participate in the long-term (Fraser and Restrepo-Estrada, 1998).

While early thinking and action of Development Communication took place in the framework of the modernization approach, current Development Communication has adopted a participatory way of thinking that led to the recent Participatory Development Approaches including Participatory Communication as one crucial instrument for development. The current view on communication is a 
fundamental two-way, interactive and participatory one, emphasizing the process of communication such as the exchange of meanings and the relationships communication is able to create (Servaes 1996). The shift in development thinking has opened the door for a much broader role for communication than under the former paradigms and made steps to leave behind the dominance and neglect of people's backgrounds and demands.

Those participatory development approaches have also influenced changes in the way media is used in development to include people into the process of 'media making'. In this coherence Ethnic media moved into the focus of development processes (Fraser, Restrepo-Estrada 1998). The current aim of Development Communication is the removal of any constraints to pave the way for a more equal and participatory society (Huesca 2002, Servaes, Jacobson and White 1996).

\subsection{Participatory Development Communication}

Predominantly two major approaches of Participatory Communication influenced the sector of Development Communication since the emergence of participatory models. These were the dialogical or critical pedagogy of Paulo Freire and the ideas of access, participation and self-management articulated in the UNESCO debates of the 1970s (Servaes 1993). Both approaches involve the notions of access and participation as the core ideas of a normative theory of alternative communication. Freire, in his 'Pedagogy of the Oppressed' (1968) stresses that many political and educational projects have failed because they have been designed from the implementers' 'view of reality', not considering and involving the people to whom the programs have been directed, except as mere objects of their action (Freire 1968: 84).The idea of Development Broadcasting, stems from this participatory school of thought, particularly the 'critical conscious' model of Paulo Freire.

\subsection{The Freirean Perspective}

The current, predominant form of Development Communication, namely Participatory Development Communication (PDC) received high contribution from the theory of Paulo Freire. The perception that Development Communication cannot change people but that it can only support them to change themselves is the centre of today's practices of employing communication technologies and strategies as part of rural development interventions (Manyozo 2004). Freire's argues that positive outcome of educational or political programs can only be generated by respecting the "particular view of the world held by the people".

The intention of his model is to prompt the individual to critically reflect on his or her own living conditions and problems. By this he premises "the right to participation and emancipation regarding social, cultural, and historical reality" as a fundamental right for everyone (Servaes 1996). Freire believed in people's ability to learn, to reflect dominating social, political and economic contradictions and consequently to be able to take actions against those oppressive elements in their lives. This is what he calls 'conscientization'.

According to Freire, in the process of 'conscientization', men begin to single out elements from their 'background awareness' and to reflect upon them (Freire 1968: 70). Stemming from his practice and theory of dialogical education he holds the view that dialogue leads to ongoing processes of reflection and creating awareness, resulting in action. He underlines mutual, horizontal dialogue between the people and between the 'oppressed' and other instances as the encounter in which reflection and resulting action is addressed to the 'world' that is meant to be transformed, to be developed (Freire 1968: 77).

By this Freire goes beyond his educational model and suggests a role of media in developing countries. His conscientization model "was designed to bring about new conditions by breaking through a culture of acceptance and silence and encourage active participation as a subject" (Richards 2001). By emphasizing the crucial importance of dialogue he points to the core importance of communication for learning and creating awareness.

\subsection{Research Findings}

The media have a big responsibility. Given their Watchdog function, news media scrutinize and hold to account the county government. In this sense, media represent and present opinions of the public. Most breakfast shows by the radio stations, act as agenda-setting and framing of events agents that keep the County leadership on its toes. 

Kenya.

In order to effectively fulfil these roles, media ought to remain neutral, objective and present information free of political bias. In so doing, media become the eyes and ears of society. They expose both the good and the evil in the private and public domains. If the people are able to make decisions they must be supplied with the right information with which to assess opinions. To this end, therefore, society needs a media that is much more equitable and pluralistic in its approach to reporting both County and National news.

The media perform important roles that help in community development including the promotion of local identity, character and culture, it provides programming that is particular to its ethnic community's identity and character. It relies principally on local content. It includes outside news and events that have a special interest or implication for its audience.

The value of content and 'localness' usually outweighs formal quality and 'professionalism', through this should not be used as an excuse for sub-standard technical production. Local language and expressions are the raw material that feeds ethnic media. They are the cement of cultural diversity which is as important for the successful future of humanity as biological diversity. This enhances the development of the ethnic community.

The Media act as mobilizing forces by providing members of the communities a kind of social barometer. They offer an understanding of the current relationship between the ethnic community and the broader society. They identify points of contention, and offer a venue for the community to debate the issues at hand and come to a consensus about the best course of action. In the issue resolution process, the media serve as mobilizing agents.

Media creates a diversity of voices and opinions on the air, through its openness to participation to all sectors and people in an ethnic community. Some discord is present in all communities; they are not the peaceful, harmonious groupings that outsiders may idealistically imagine. Discord may be caused by differing interests, by differing linguistic or religious backgrounds, or even by some ancient feud. The acknowledgement of conflict is necessary for democracy and for democratic communities. Through an understanding of why conflict exists, communities can understand themselves better and pave the way to resolve conflicts. A function of the media is to try objectively to air all sides of a discussion, without itself taking sides.

The media provides a diversity of programmes in a variety of formats and styles. For example, roundtable discussions, reportage, interviews, call-in programmes and live broadcasts of meetings in the community. Audience preferences are taken into account in deciding what formats are most suitable.

The content also covers a wide rage of topics, again in accordance with the expressed desires and needs of the audience. Content is mainly determined by the lifestyles and livelihood of the ethnic community and by the problems it faces. In rural areas, themes such as health, farming, fishing, environment, credit, marketing of produce and small-scale enterprises, usually feature prominently, but always set in the context of the ethnic community's actual situation.

News broadcast may also focus on different types of content. They may cover only local events and issues, or they may include national items that have local relevance, or they may even broadcast national and international news per se in the case of a remote Ethnic community with no access to other media channels.

The media encourages open dialogue and democratic process. The ancient Greeks, who invented democracy, conducted their political debate in public. All those who wished could be present at the meetings to listen and voice their views. Sheer numbers of people make this impossible today, and for this reason, democratic process has become distant from ordinary citizens. Typically, once politicians are elected, their contact with their electorates is limited, and they go about their tasks without much further consultation or debate with them.

It is a function of the media to provide an independent platform for interactive discussion about matters and decisions of importance to its community. This is in keeping with the decentralization process now being implemented in many countries including Kenya, a purpose of which is to bring democratic decision-making closer to the people concerned. 
Role of Media in Promoting Accountability and Transparency in Kakamega County Government Kenya.

However, for social and economic progress to take place, democratic processes cannot start and finish in the community. They must reach into the government and private institutions operating in the community, as well as to policy makers and authorities at the local, regional, and even national level. The public debates aired by the media will certainly be heard by locally-based staff of county government and private institutions, and the radio's content should be relayed by them to their superiors. This lays the foundation for development initiatives that are responsive to the community's felt needs and possibilities. In sum, the core of democratic process is the ability of people to hear and make themselves heard. The media provides the forum for that to happen.

The media promotes development and social change in the rural areas. People in poor communities tend to be fatalistic about their situation. They will all have individual perceptions, but development cannot take place on the basis of these. What is needed is a collective perception of the local reality and of the options for improving it. This can only be achieved through internal discussions within the ethnic community about its situation, the causes, and possible actions for improvement.

\section{REFERENCES}

[1] Anderson, Benedict. 1991. Imagined communities. London: Ball-Rokeach, S. J. (1998). A theory of media power and a theory of media use: Different stories, questions, and ways of thinking. Mass Communication and Society, 1 (1), 5-40

[2] Ball-Rokeach, S. J. (1985). The Origins of Individual Media-System Dependency: A sociological framework. Communication Research, 12 (4), 485.

[3] Dearing, J. W., \& Rogers, E. M. (1996). Agenda-setting. Thousand Oaks, CA: Sage Fraser, C. and Restrepo-Estrada, S., 1998. Communication for Development - Human Change for Survival, London: I.B. Tauris Publishers.

[4] Freire, P., 1968. Pedagogy of the Oppressed, New York: Herder and Herder.

[5] Huesca, R., 2002. Participatory approaches to communication for development, in Mody, B. and Gudykunst, W. (eds) Handbook of International and Intercultural Communication, Thousand Oaks: Sage Publications.

[6] Jacobson T. L., 2004. Participatory Communication for Development and the African Philosophy Debate, in Okibo, E. and Eribo, F., Development and Communication in Africa, p. 65-78. Oxford: Rowman \& littlefield.

[7] McCombs, M. and Reynolds, A. (2002) 'News influence on our pictures of the world', in Bryant, J. and Zillimann, Dolf (ed.), 'Media Effects', 2d ed., Lawrence Erlbaum Associates, Mahwah, J, 1-16.

[8] Riggins, Stephen Harold (1992). "The Media Imperative: Ethnic Minority Survival in the Age of Mass Communication." In Stephen Harold Riggins, Ethnic Minority Media: An International Perspective

[9] Newbury Park, Calif.: Sage, pp. 1-20 Richards, M., 2001. The Freirean Legacy, Development, Communication, and Pedagogy, in Richads, M., Thomas,

[10] P. N. and Nain, Z., Communication and Development -The Freirean Connection. Cresskill: Hampton Press.

[11] Rogers, Everett M. [1962] (1995): Diffusion of Innovation. New York: Free Press. 4. Aufl. Schramm, W., 1964. Mass Media and National Development, Stanford, CA: Stanford University Press.

[12] Servaes, J., 1993. Development Communication Approaches in an International Perspective, in Open M., Media

[13] Participatory Communication for Social Change, p. 29-43. London: Sage Publications. Turner, J. C. (1982). Toward a cognitive redefinition of the social group. In H. Tajfel (Ed.), Social identity and intergroup behavior (pp. 15-40). Cambridge, England: Cambridge University Press

Citation: Mr. Wafula Nyongesa. "Role of Media in Promoting Accountability and Transparency in Kakamega County Government - Kenya". International Journal of Media, Journalism and Mass Communications (IJMJMC), vol 7, no. 1, 2021, pp. 04-08 doi: http://dx.doi.org/10.20431/2454-9479.0701002.

Copyright: (C) 2021 Authors. This is an open-access article distributed under the terms of the Creative Commons Attribution License, which permits unrestricted use, distribution, and reproduction in any medium, provided the original author and source are credited. 